\title{
BIOINFORMATICS AND CHEMINFORMATICS STUDY OF CARBAZOLE DERIVATIVES - P3C7, P3C7-A20 P3C7-S243, AND DE NOVO 2,5-DISUBSTITUTED 1,3,4-OXADIAZOLE DERIVATIVES
}

\author{
NATALIA GUMA (TANASIEV) ${ }^{1}$, ALEXANDRA TEODORA BORDEI (TELEHOIU) ${ }^{2 *}$, \\ CARMEN LIMBAN $^{2}$, CĂTĂLINA SOGOR ${ }^{1}$, LAURA MANOLIU ${ }^{1}$, SPERANȚA AVRAM ${ }^{1}$ \\ ${ }^{1}$ Department of Anatomy, Animal Physiology, and Biophysics, Faculty of Biology, University of Bucharest, 36-46 M. \\ Kogălniceanu Boulevard, 050107, Bucharest, Romania \\ ${ }^{2}$ Department of Pharmaceutical Chemistry, Faculty of Pharmacy, "Carol Davila” University of Medicine and Pharmacy, 6 \\ Traian Vuia Street, 020956, Bucharest, Romania
}

*corresponding author: alexandratelehoiu@yahoo.com

Manuscript received: January 2020

\begin{abstract}
Recently, the neuroprotective effects of several carbazole derivatives have been mentioned, but without a clear molecular mechanism of action being established. In this article, by using computational biology tools, we proposed the pharmacodynamic features of de novo 2,5-disubstituted 1,3,4-oxadiazole derivatives, compared to P3C7, P3C7-A20 P3C7-S24, already known as neuroprotective compounds. Besides, for these compounds, were established the predicted pharmacokinetic profiles (ADME-Tox), including absorption, distribution, metabolism, excretion, and toxicology. Our computational results showed that: (i) de novo compounds $1 \mathrm{~b}, 1 \mathrm{c}$ and $1 \mathrm{~d}$ presented biological activity for nicotinamide phosphoribosyltransferase, which presumes that these compounds have neuroprotective effects, similarly with P3C7-A20; (ii) ADME-Tox results, with an emphasis on toxicity and BBB and CNS permeabilities, show that compound 1c could be a suitable drug candidate. Our computational results proposed de novo 2,5-disubstituted 1,3,4-oxadiazole derivatives 1a-d, in particular 1c, as new good candidates for neuroprotective effects.
\end{abstract}

\section{Rezumat}

Recent, au fost menționate efectele neuroprotectoare ale câtorva derivaţi de carbazol, dar fară stabilirea unui mecanism molecular de acțiune clar. In acest articol, utilizând instrumente biologice computaționale, am propus caracteristicile farmacodinamice ale derivaților de novo 2,5 disubstituiți ai 1,3,4-oxadiazolului, comparativ cu P3C7, P3C7-A20 P3C7-S24, cunoscute deja sub formă de compuși neuroprotectori. În plus, pentru acești compuși, au fost stabilite profilurile farmacocinetice (ADME-Tox), incluzând absorbția, distribuția, metabolismul, excreția și toxicologia. Rezultatele noastre de calcul au arătat că: (i) compușii de novo $1 \mathrm{~b}, 1 \mathrm{c}$ și 1d au prezentat activitate biologică pe nicotinamidă fosforibosiltransferază, care presupune că acești compuşi au efecte neuroprotectoare, în mod similar cu P3C7-A20; (ii) rezultatele ADME-Tox, cu accent pe toxicitate și permeabilitățile BBB și SNC, arată că derivatul 1c ar putea fi un candidat adecvat pentru un nou medicament. Rezultatele noastre de calcul au propus derivații de novo 2,5-disubstituiți ai 1,3,4-oxadiazolului 1a-d, în special $1 \mathrm{c}$, ca noi candidați pentru efectele lor neuroprotectoare.

Keywords: neuroprotection, carbazole derivatives, bioinformatics, cheminformatics, brain molecular targets

\section{Introduction}

Carbazole and its derivatives present a wide therapeutic application in medicine such as antitumoural activity [1], antimicrobial activity on Staphylococcus aureus, Escherichia coli, Xanthomonas oryzae, Xanthomonas axonopodis and Pseudomonas syringae [2-4] or neurogenesis agents [4-7]. Here, we wanted to deepen the possible biological activities of de novo carbazole derivatives on the brain, by using bioinformatics and cheminformatics tools. It was mentioned that oxidative stress plays an important role in several neurodegenerative diseases and cerebral ischemic injury. The literature data mentioned that the carbazole derivatives presented antioxidant effects in vitro.
Furukawa Y et al. synthesized carbazole compounds that presented in vitro antioxidant effect [4] and they reported that the carbazole derivative, namely 3ethoxy-1-hydroxy-8-methoxy-2-methylcarbazole-5carbaldehyde, presented the ability to protect neuron cells from hydrogen peroxide-induced cell death. On the other hand, it was mentioned that in the nervous system, carbazole derivatives played an important role in neurogenesis. For example, an aminopropyl carbazole namely P7C3 [5, 6] and its derivatives namely P7C3-A20 [7] and P7C3-S243 [8] may present neurogenesis effects, but their molecular mechanisms in the brain have not been completely elucidated. There is a study [5] indicating that $\mathrm{P} 7 \mathrm{C} 3$ promotes the expression of neurogenesis by activation of the 
cAMP/PKA-dependent and Akt/GSK3-associated $\beta$-catenin through positive allosteric stimulation of GLP-1R. Also, it was suggested that during neuroinflammation, P7C3 suppresses the expression of lipopolysaccharide-induced pro-inflammatory factors, but not the anti-inflammatory factors in microglia $[8,9]$. A complex study involving the experimental and bioinformatics methods [8] reported neuroprotective properties of P7C3-S243 in the cell membrane by inhibiting the direct interaction between the lipid bilayer and beta-amyloid.

Hill CS et al. [7] reported that P7C3-A20 reduces neurological deficits when it is administered to murine in vivo models of traumatic brain injury and, it was postulated that P7C3-A20 exerts its activity through activation of enzyme nicotinamide phosphoribosyltransferase.

Traumatic brain injury is a severe public health problem around the world. Studies have shown that the administration of P7C3 [10] and P7C3-A20 [11] derivatives after traumatic brain injury leads to improved brain activity by an increased flux of nicotinamide adenine dinucleotide in mammalian cells. An interesting study [11] mentioned that P7C3-A20 treatment was correlated with a critical decrease of cortical and hippocampal atrophy and increased neurogenesis in the subventricular zone and hippocampal dentate gyrus subgranular zone.

De Jesús-Cortés H et al. [12] have remarked the neuroprotective effects of P7C3-A20 and P7C3-S243 in the rat 6-hydroxydopamine (6-OHDA) model of Parkinson's disease. Study results showed that P7C3S243 administration induces (i) blocking dopaminergic neuron cell death in the substantia nigra; (ii) protection of dopamine and its metabolites in ipsilateral striatum; (iii) preservation of normal motor behaviour; and (iv) P7C3-A20 restored postnatal hippocampal neurogenesis.

Based on our previous studies regarding the biological activity of carbazole derivatives [13] and applied bioinformatics tools in various disorders treatments [14, 15], here, we aimed to study the possible pharmaceutical effects of de novo 2,5-disubstituted 1,3,4-oxadiazole derivatives by structural and functional similarities with P7C3 and its derivatives P7C3-A20 and P7C3S243.

In medical chemistry, when de novo compounds are studied for their pharmacological effects, a few steps are followed, among them, the drug-like features and pharmacodynamics/pharmacokinetics profiles are calculated. According to this, we predicted the druglike features of de novo 2,5-disubstituted 1,3,4oxadiazole derivatives, namely compounds 1a-d. Furthermore, to establish the biological activity of de novo 2,5-disubstituted 1,3,4-oxadiazole derivatives on the brain, we made computational predictions for de novo 2,5-disubstituted 1,3,4-oxadiazole derivatives to be ligands for various human molecular targets.
Also, we predicted the critical features regarding the pharmacokinetic profiles of de novo 2,5-disubstituted 1,3,4-oxadiazole derivatives.

\section{Materials and Methods}

Molecular modelling and minimum energy evaluation of carbazole derivatives

In this study, the chemical structures of 2,5-disubstituted 1,3,4-oxadiazole compounds 1a-d, P7C3, P7C3-A20 and P7C3-S243 were built using molecular modelling tools from Discovery Studio software [16]. Initially, the chemical structures were obtained in 2D structures, and then, by using the Builder module from Discovery Studio software, the spatial structure of chemical compounds with complete hydrogen atoms was obtained as a .mol 2 file. The structure's minimum potential energies were calculated using mechanistic force field MMFF94x, at a gradient of 0.05 . After calculating the minimum potential energy, the Gasteiger electric charges for each molecule were downloaded from the Discovery Studio library. Also, the SMILES code overall molecules were obtained. The smiles code, IUPAC name and 2D structures of these compounds are presented in Table I.

Drug-like character and bioavailability evaluation of 2,5-disubstituted 1,3,4-oxadiazole compounds la-d, P7C3, P7C3-A20 and P7C3-S243

To evaluate the pharmacological character of compounds, the Lipinski rules and the Veber rules (bioavailability) were applied [17, 18]. The Lipinski's rule of five refers to the possibility of drug-like features of small molecules if the following criteria are respected: (i) no more than 5 hydrogen bond donors in the structure; (ii) no more than 10 hydrogen bond acceptors in the structure; (iii) molecular mass less than 500 Daltons; (iv) octanol-water partition coefficient (MlogP) does not exceed 5. Veber rule imposed for a good bioavailability as (i) 10 or fewer rotatable bonds in structure, (ii) less than 12 hydrogen bond donors or acceptors in total in the structure; (iii) topological polar surface area (TPSA) less than $140 \AA^{2}$ [17]. To calculate the Lipinski and Veber rules, the SMILES file of the molecules (Table I) was loaded into the ExPASy Bioinformatics Resource Portal and the cheminformatics database Molinspiration [19, 20]. Computational pharmacokinetics profiles (ADME-Tox) of 2,5-disubstituted 1,3,4-oxadiazole compounds la-d versus P7C3, P7C3-A20 and P7C3-S243

For the assessment of ADME-Tox features (Absorption, Distribution, Metabolism, Excretion and Toxicity), the SMILES files of 1a-d compounds, P7C3, and its derivatives were loaded in pkCSM database [21]. In our study, we evaluated quantitatively and qualitatively an important number of ADME-Tox features, but here we will present the most significant features such as (1) Absorption - (i) human intestinal absorption (in \%), a molecule with an absorbance of less than $30 \%$ is 
FARMACIA, 2020, Vol. 68, 4

considered to be poorly absorbed; (2) Distribution (i) blood-brain barrier (BBB) permeability (Numeric $(\log \mathrm{BBB}))$, if $\log \mathrm{BBB}>0.3$, that means the tested compounds have good $\mathrm{BBB}$ permeability, and if $\log \mathrm{BBB}<-1$, they have low BBB permeability; (ii) central nervous system (CNS) permeability (Numeric $(\log$ Ps $))$, if $\log$ Ps $>-0.2$, the compounds would penetrate CNS, and if $\log$ Ps $<-3$, they wouldn't enter CNS; (3) Metabolism - of CYP2D6 substrate and inhibitors; (4) Excretion - total renal and hepatic clearance; (5) Toxicity - (i) AMES toxicity (mutagenic potential of a drug), (ii) hERG I inhibitor/hERG II inhibitor; (iii) Hepatotoxicity and (iv) Skin sensitization.

The IUPAC name, SMILES code and 2D structures of carbazole derivatives

\begin{tabular}{|c|c|c|c|}
\hline CRT & IUPAC NAME & SMILE & 2D STRUCTURE OF COMPOUNDS \\
\hline 1 & $\begin{array}{l}\text { 1-(3,6-dibromo-carbazol-9- } \\
\text { yl)-3-phenylamino-propan-2- } \\
\text { ol (P7C3) }\end{array}$ & $\begin{array}{l}\mathrm{OC}(\mathrm{CNc} 1 \mathrm{ccccc} 1) \mathrm{Cn} 4 \mathrm{c} 2 \mathrm{ccc}( \\
\mathrm{Br}) \mathrm{cc} 2 \mathrm{c} 3 \mathrm{cc}(\mathrm{Br}) \operatorname{ccc} 34\end{array}$ & \\
\hline 2 & $\begin{array}{l}\mathrm{N}-(3-(3,6-\text { dibromo-9H- } \\
\text { carbazol-9-yl)-2- } \\
\text { fluoropropyl)-3- } \\
\text { methoxyaniline (P7C3-A20) }\end{array}$ & $\begin{array}{l}\mathrm{COc} 4 \mathrm{cccc}(\mathrm{NCC}(\mathrm{F}) \mathrm{Cn} 3 \mathrm{c} 1 \mathrm{cc} \\
\mathrm{c}(\mathrm{Br}) \mathrm{cc} 1 \mathrm{c} 2 \mathrm{cc}(\mathrm{Br}) \mathrm{ccc} 23) \mathrm{c} 4\end{array}$ & \\
\hline 3 & $\begin{array}{l}\text { N-[3-(3,6-dibromocarbazol- } \\
\text { 9-yl)-2-fluoropropyl]-6- } \\
\text { methoxypyridin-2- amine } \\
\text { (P7C3-S243) }\end{array}$ & $\begin{array}{l}\mathrm{COc} 4 \mathrm{cccc}(\mathrm{NCC}(\mathrm{F}) \mathrm{Cn} 3 \mathrm{c} 1 \mathrm{cc} \\
\mathrm{c}(\mathrm{Br}) \mathrm{cc} 1 \mathrm{c} 2 \mathrm{cc}(\mathrm{Br}) \mathrm{ccc} 23) \mathrm{n} 4\end{array}$ & \\
\hline 4 & $\begin{array}{l}\mathrm{N}^{\prime}-(2-(6-\mathrm{chloro}-9 H \text { - } \\
\text { carbazol-2-yl)propanoyl)-4- } \\
\text { methoxybenzohydrazide (1a) }\end{array}$ & $\begin{array}{l}\mathrm{COc} 4 \operatorname{ccc}(\mathrm{C}(=\mathrm{O}) \mathrm{NNC}(=\mathrm{O}) \mathrm{C} \\
(\mathrm{C}) \mathrm{c} 1 \mathrm{ccc} 3 \mathrm{c}(\mathrm{c} 1)[\mathrm{nH}] \mathrm{c} 2 \mathrm{ccc} \\
(\mathrm{Cl}) \mathrm{cc} 23) \mathrm{cc} 4\end{array}$ & $\mathrm{CH}_{3}$ \\
\hline 5 & $\begin{array}{l}\text { N'-(2-(6-chloro-9H- } \\
\text { carbazol-2-yl)propanoyl)-4- } \\
\text { nitrobenzohydrazide (1b) }\end{array}$ & $\begin{array}{l}\mathrm{CC}(\mathrm{C}(=\mathrm{O}) \mathrm{NNC}(=\mathrm{O}) \mathrm{c} 1 \mathrm{ccc}([ \\
\mathrm{N}+](=\mathrm{O}) \mathrm{O}) \mathrm{cc} 1) \mathrm{c} 2 \mathrm{ccc} 4 \mathrm{c}(\mathrm{c} 2)[ \\
\mathrm{nH}] \mathrm{c} 3 \mathrm{ccc}(\mathrm{Cl}) \mathrm{cc} 34\end{array}$ & $\mathrm{CH}_{3}$ \\
\hline 6 & $\begin{array}{l}\text { N'-(2-(6-chloro-9H- } \\
\text { carbazol-2-yl)propanoyl)-4- } \\
\text { (trifluoromethoxy)benzohydr } \\
\text { azide (1c) }\end{array}$ & $\begin{array}{l}\mathrm{CC}(\mathrm{C}(=\mathrm{O}) \mathrm{NNC}(=\mathrm{O}) \mathrm{c} 1 \mathrm{ccc}( \\
\mathrm{OC}(\mathrm{F})(\mathrm{F}) \mathrm{F}) \mathrm{cc} 1) \mathrm{c} 2 \mathrm{ccc} 4 \mathrm{c}(\mathrm{c} 2)[ \\
\mathrm{nH}] \mathrm{c} 3 \mathrm{ccc}(\mathrm{Cl}) \mathrm{cc} 34\end{array}$ & $\mathrm{CH}_{3}$ \\
\hline 7 & $\begin{array}{l}\text { N'-(2-(6-chloro-9H- } \\
\text { carbazol-2-yl)propanoyl)-4- } \\
\text { ethoxybenzohydrazide (1d) }\end{array}$ & $\begin{array}{l}\mathrm{CCOc} 4 \operatorname{ccc}(\mathrm{C}(=\mathrm{O}) \mathrm{NNC}(=\mathrm{O}) \\
\mathrm{C}(\mathrm{C}) \mathrm{c} 1 \mathrm{ccc} 3 \mathrm{c}(\mathrm{c} 1)[\mathrm{nH}] \mathrm{c} 2 \mathrm{ccc}( \\
\mathrm{Cl}) \mathrm{cc} 23) \mathrm{cc} 4\end{array}$ & $\mathrm{CH}_{3}$ \\
\hline
\end{tabular}


FARMACIA, 2020, Vol. 68, 4

Computational pharmacodynamic profiles of 2,5disubstituted 1,3,4-oxadiazole compounds 1a-d, P7C3, P7C3-A20 and P7C3-S243

In order to identify the molecular targets of these compounds, we used bioinformatics tools - Molinspiration and SwissTargetPrediction, by loading the SMILES file (Table I). Molinspiration software offers a wide range of chemoinformatics tools that supports the handling and processing of molecules, including conversion of SMILES and SDfile, normalization and fragmentation of molecules, calculation of different molecular properties required in QSAR, molecular modelling and drug design $[10,22,23]$. Here, we used Molinspiration/Module-Predicted bioactivity. In this module, we evaluated the bioactivity score of molecules, on the level of metabotropic receptors active sites (GPCR), ion channel modulators, a kinase inhibitor, nuclear receptor ligand, protease inhibitor and enzyme inhibitor [24].

The SwissTargetPrediction software allows us to predict the targets of a small molecule, using molecular similarities, comparing the molecule with the database containing 280.000 active compounds, with more than 2000 targets, from 5 different organisms.

The different output files contain specific targets and the probability of compounds to be a ligand for those specific targets.

\section{Results and Discussion}

Drug likeness evaluation of 2,5-disubstituted 1,3,4oxadiazole compounds 1a-d, P7C3, P7C3-A20 and P7C3-S243

By calculating the molecular descriptors using Lipinski and Veber rules, we noticed that compounds 1a-d and P7C3 abide by Lipinski and Veber rules simultaneously and have a good bioavailability score, according to the Veber rule. Instead, P7C3-A20 and P7C3-S243 do not follow the Lipinski rules regarding hydrophobicity and molecular weight (Table II).

Table II

Lipinski and Veber rules validation, bioavailability score and predicted molecular weight (MW) of 2,5disubstituted 1,3,4-oxadiazole compounds 1a-d, P7C3, P7C3-A20 and P7C3-S243

\begin{tabular}{|l|c|c|c|c|}
\hline Compound & Lipinski Rule & Veber Rule & Bioavailability Score & MW (g/mol) \\
\hline 1a & YES & YES & 0.55 & 421.88 \\
\hline 1b & YES & YES & 0.55 & 436.86 \\
\hline 1c & YES & YES & 0.55 & 475.85 \\
\hline 1d & YES & YES & 0.55 & 435.91 \\
\hline P7C3 & Yes; 1 violation: MlogP > 5 & YES & 0.55 & 474.19 \\
\hline P7C3-A20 & No; 2 violations: MW > 500, MlogP > 5 & YES & 0.17 & 506.21 \\
\hline P7C3-S243 & No; 2 violations: MW > 500, MlogP > 5 & YES & 0.17 & 507.19 \\
\hline
\end{tabular}

Related to our results, we can mention that de novo compounds 1a-d proposed here may present potential drug features and can be considered in further pharmacokinetic and pharmacodynamic studies. Our results showed that compound $1 \mathrm{c}$ is very similar in molecular weight and bioavailability score with P7C3. Compounds $1 \mathrm{a}, 1 \mathrm{~b}$ and $1 \mathrm{~d}$ also presented good bioavailability. Computed the pharmacokinetics profiles (ADME-Tox) of 2,5-disubstituted 1,3,4-oxadiazole compounds la-d, P7C3, P7C3-A20 and P7C3-S243

To identify critical absorption and distribution features of de novo compounds versus $\mathrm{P} 7 \mathrm{C} 3$ and its derivatives, we computed the intestinal absorption, blood-brain barrier permeability as well as central nervous system permeability. Our results have shown that a good intestinal absorption was recorded for de novo compounds (the values of human intestinal absorption varies from 88.13 (1b) to 91.02 (1a), very near to P7C3 and its derivatives (Table III). Our results suggested that compounds 1a-d may pass the digestive level and could be proposed for the oral administration.

In medicinal chemistry, it's very important to calculate the BBB permeability. We noticed that compounds 1a-d presented a moderate permeability for BBB (the value ranges from -1.15 (1c) to -0.84 (1a)), while P7C3 and its derivatives recorded positive values for $\log$ BBB. These results may lead to new opportunities for increasing the permeability of the BBB by improving the chemical structures of 1a-d.

In literature data, the compound P7C3 and its derivatives were presented as good candidates for brain disorders. Furthermore, we calculated the CNS permeability of compounds 1a-d and these values were compared with CNS permeability of P7C3 and its derivatives. Our results have shown that compounds 1a (-1.96), $1 \mathrm{~b}(-2.06)$ and $1 \mathrm{~d}(-1.97)$ presented a small capacity to cross the CNS membranes compared to $\mathrm{P} 7 \mathrm{C} 3$ and its derivative compounds. Instead, compound 1c (-1.82) has a close CNS log value with P7C3-S243 (-1.65). Our results lead to the prediction that compound 1c could be proposed as a good candidate for the central nervous system regarding its possibility to cross CNS membranes. Similar to previous BBB results mentioned before, our prediction of $\mathrm{CNS}$ permeability at compounds $1 \mathrm{a}, 1 \mathrm{~b}$, and $1 \mathrm{~d}$ gives us the possibility for further studies, to increase their CNS permeability by making probably minor changes to their chemical structures. 
Predictive Absorption and Distribution profiles of 2,5-disubstituted 1,3,4-oxadiazole compounds 1a-d, P7C3,

\begin{tabular}{|l|c|c|c|}
\hline \multicolumn{1}{|c|}{ Compound } & $\begin{array}{c}\text { Intestinal absorption } \\
\text { (human) }(\boldsymbol{\%})\end{array}$ & $\begin{array}{c}\text { BBB permeability } \\
\text { (Numeric }(\log \text { BB) })\end{array}$ & $\begin{array}{c}\text { CNS permeability } \\
\text { (Numeric (log PS) })\end{array}$ \\
\hline 1a & 91.02 & -0.84 & -1.96 \\
\hline 1b & 88.13 & -0.99 & -2.06 \\
\hline 1c & 89.33 & -1.15 & -1.82 \\
\hline 1d & 90.61 & -0.89 & -1.97 \\
\hline P7C3 & 87.60 & 0.28 & -0.82 \\
\hline P7C3-A20 & 87.92 & 0.51 & -1.20 \\
\hline P7C3-S243 & 90.98 & 0.30 & -1.65 \\
\hline
\end{tabular}

Regarding the metabolization process, we noticed that (i) P7C3 plays a role of substrate/inhibitor for CYP2D6, but not for its derivatives; (ii) compounds 1a-d are not substrates/inhibitors of CYP2D6.

OCT2 is a primarily renal uptake transporter that is expressed on the basolateral side of proximal tubule cells [25]. The role of OCT2 as the first step in active renal secretion of cationic drugs remains important.
Current FDA and EMA guidance recommend evaluation of OCT2 liabilities for drugs with high renal elimination, or which are likely to be co-administered with OCT2 substrates such as metformin [26]. By predicting the OCT2 renal substrate, we noticed that all compounds involved in the study, do not present OCT2 affinities (Table IV).

Table IV

Predictive Metabolization and Elimination profiles of 2,5-disubstituted 1,3,4-oxadiazole compounds 1a-d, P7C3,

P7C3-A20 and P7C3-S243

\begin{tabular}{|l|c|c|c|c|}
\hline Compound & CYP2D6 substrate & CYP2D6 inhibitor & Total Clearance & Renal OCT2 substrate \\
\hline 1a & NO & NO & -0.228 & NO \\
\hline 1b & NO & NO & -0.671 & NO \\
\hline 1c & NO & NO & -0.334 & NO \\
\hline 1d & NO & NO & -0.277 & NO \\
\hline P7C3 & YES & YES & 0.111 & NO \\
\hline P7C3-A20 & NO & NO & 0.218 & NO \\
\hline P7C3-S243 & NO & NO & 0.248 & \\
\hline
\end{tabular}

A very important part of our study was represented by the prediction of carbazole derivatives toxicity. Here, we presented the results of AMES, hepatotoxicity, skin sensitization and the activity of predictive inhibition of compounds in hERG I and hERG II. Our results have shown that (i) compounds 1a, 1b, 1d, P7C3 and P7C3-A20 presented AMES toxicity; (ii) encouraging result was obtained for 1c, which presents no AMES toxicity, similarly to P7C3-S243; (iii) compounds 1a-d, P7C3-A20 and P7C3-S243 presented hepatotoxicity, excepted compound P7C3; (iv) suitable results were obtained regarding skin sensitization, all compounds considered for study have not shown toxicity to the skin (Table V).

Table V

Predictive toxicity profile of 2,5-disubstituted 1,3,4-oxadiazole compounds 1a-d, P7C3, P7C3-A20 and P7C3-

\begin{tabular}{|l|c|c|c|c|c|}
\hline Compound & AMES toxicity & hERG I inhibitor & hERG II inhibitor & Hepatotoxicity & Skin Sensitisation \\
\hline 1a & YES & NO & YES & YES & NO \\
\hline 1b & YES & NO & YES & YES & NO \\
\hline 1c & NO & NO & YES & YES & NO \\
\hline 1d & YES & NO & YES & YES & NO \\
\hline P7C3 & YES & NO & YES & NO & NO \\
\hline P7C3-A20 & YES & NO & YES & YES & NO \\
\hline P7C3-S243 & NO & NO & YES & YES & NO \\
\hline
\end{tabular}

Analyses of compounds 1a-d toxicity have shown that the compound 1c exhibited a similar pharmacokinetic profile with P7C3-S243 and 1c has low toxicity and can be proposed as a possible safe drug. Also, compounds 1a-d can be considered as a safe drug for skin use.
Pharmacodynamic profiles and molecular similarity in carbazole derivatives series

An important aim of our study was represented by the prediction of the pharmacodynamic features of compounds. By accessing the Molinspiration tools, we predicted the probability as studied compounds to be ligands: (i) metabotropic receptors (GPCR); 
(ii) ion channels; (iii) kinases; (iv) nuclear receptors and (v) protease.

Based on our computational results, we noticed that (i) studied carbazole derivatives do not present the affinity for ion channels and nuclear receptors; (ii) compounds 1a-d have no affinity for proteases; (iii) regarding the kinase affinity, compounds $1 \mathrm{a}$ and $1 \mathrm{c}$ have an insignificant probability to be ligands, in contrast with P7C3-A20 (0.30) and P7C3-S243 (0.52); (iv) compound $1 \mathrm{~b}(0.12)$ and $1 \mathrm{~d}(0.07)$ have presented moderate probability to be kinase ligands, in a similar manner for P7C3 (0.10) (Table VI).

Based on our results, we assume that compounds $1 \mathrm{~b}$ and 1d may present attractive targets for further studies on pharmacodynamic characteristics than P7C3.

The predicted targets of 2,5-disubstituted 1,3,4-oxadiazole compounds 1a-d, P7C3, P7C3 A20 and P7C3-S243 by Molinspiration informatic tool

\begin{tabular}{|l|c|c|c|c|c|}
\hline Compound & GPCR ligand & Ion channel modulator & Kinase inhibitor & Nuclear receptor ligand & Protease inhibitor \\
\hline 1a & -0.10 & -0.23 & 0.03 & -0.48 & -0.17 \\
\hline 1b & -0.19 & -0.21 & 0.12 & -0.54 & -0.24 \\
\hline 1c & -0.02 & -0.06 & 0.02 & -0.28 & -0.15 \\
\hline 1d & -0.13 & -0.23 & 0.07 & -0.45 & -0.22 \\
\hline P7C3 & -0.08 & -0.09 & 0.10 & -0.36 & -0.20 \\
\hline P7C3-A20 & 0.05 & -0.09 & 0.30 & -0.06 & -0.11 \\
\hline P7C3-S243 & 0.27 & 0.08 & 0.52 & -0.01 & 0.19 \\
\hline
\end{tabular}

For better accuracy of predictive molecular targets of compounds, we accessed the SwissTargetPrediction database [22]. With this tool, we estimated the most probable macromolecular targets of small molecules. Target prediction is calculated on a combination of 2D and 3D similarity with 370,000 known compounds

with compounds studied on more than 3,000 proteins. Considering the literature data, which mentions nicotinamide phosphoribosyltransferase as an enzyme target for P3C7 derivatives due to its action in the brain, we searched for this enzyme as a possible target for compounds 1a-d. (Table VII).

Table VII

The molecular targets of 2,5-disubstituted 1,3,4-oxadiazole compounds 1a-d, P7C3, P7C3 A20 and P7C3-S243 by SwissTargetPrediction

\begin{tabular}{|l|c|c|c|}
\hline Compound & Nicotinamide phosphoribosyltransferase & Probability (\%) & The number of similarities compounds (3D) \\
\hline 1a & - & - & - \\
\hline 1b & YES & 13 & 138 \\
\hline 1c & YES & 10 & 5 \\
\hline 1d & YES & 12 & 158 \\
\hline P7C3 & - & - & - \\
\hline P7C3-A20 & YES & 11 & 178 \\
\hline P7C3-S243 & NO & - & \\
\hline
\end{tabular}

Our results have shown that compounds $1 \mathrm{~b}(13), 1 \mathrm{c}$ (10) and 1d (12) presented affinity for nicotinamide phosphoribosyltransferase in a similar probability with P7C3-A20 (11) (Table VII). These findings open up new ways of studying compounds $1 \mathrm{~b}-\mathrm{d}$ effects in the brain, probably with a molecular mechanism similar to P7C3-A20.

In our study, it was interesting to predict other possible molecular targets for compounds 1a-d. Our results showed that 1a was predicted as a possible ligand for neutrophil elastase (an enzyme developed by neutrophils and macrophages during inflammation with $54 \%$ probability when 1a was compared with 114 other ligands with neutrophil elastase). This led to the hypothesis that 1a can be a good anti-inflammatory candidate. Also, we have predicted that $1 \mathrm{~d}$ may have an affinity for hepatocyte growth factor receptor with a $53 \%$ probability when $1 \mathrm{~d}$ similarity has been compared with other 397 hepatocyte growth factor receptor ligands. 1d may play the role of neutrophil elastase ligand with a $50 \%$ probability when 1a similarity has been compared with other 135 neutrophil elastase ligands. We can propose $1 \mathrm{~d}$ also as a good anti-inflammatory candidate.

\section{Conclusions}

We studied the complete pharmacokinetics and pharmacodynamics profiles of four de novo 2,5disubstituted 1,3,4-oxadiazole derivatives (1a-d), in comparison with P7C3, P7C3-A20 and P7C3-S243. We noticed that for de novo compounds 1a-d druglike and bioavailability rules were abided. Pharmacokinetic features of compounds la-d lead to the conclusion that the compound $1 \mathrm{c}$ has presented reduced toxicity and has a good CNS permeability. Pharmacodynamic results lead to the conclusion that compounds $1 \mathrm{~b}, 1 \mathrm{c}$, 1d and P7C3-A20 have the nicotinamide phosphoribosyltransferase as a common molecular target and probably could develop specific brain actions. We conclude 
that compounds $1 \mathrm{~b}-\mathrm{d}$ are suitable for future studies as good candidates in the treatment of brain diseases.

\section{Acknowledgement}

This work was supported by a grant of the Romanian Ministry of Research and Innovation, CCCDIUEFISCDI, project number PN-III-P1-1.2-PCCDI2017-0728/2018, contract no 693/2018, within PNCDI III.

\section{Conflict of interest}

The authors declare no conflict of interest.

\section{References}

1. Li G, Tang H, Liu C, Liao X, Li S, Shu Z, Yu H, Yang P, One-step synthesis of methylene-bridged bis-carbazole and evaluation of its antitumor activity and G-quadruplex DNA binding property. Bioorg Chem., 2019; 90: 103074.

2. Heredia DA, Martínez SR, Durantini AM, Pérez ME, Mangione MI, Durantini JE, Antimicrobial Photodynamic Polymeric Films Bearing Biscarbazol Triphenylamine End-Capped Dendrimeric Zn(II) Porphyrin. ACS Appl Mater Interf., 2019; 11(31): 27574-27587.

3. Bordei (Telehoiu) AT, Nuță DC, Muşat GC, Missir AV, Căproiu MT, Dumitraşcu F, Zarafu I, Ioniţă P, Bădiceanu CD, Limban C, Ozon EA, Microwave assisted synthesis and spectroscopic characterization of some novel Schiff bases of carprofen hydrazide. Farmacia, 2019; 67(6): 955-962.

4. Furukawa Y, Sawamoto A, Yamaoka M, Nakaya M, Hieda Y, Choshi T, Hatae N, Okuyama S, Effects of Carbazole Derivatives on Neurite Outgrowth and Hydrogen Peroxide Induced Cytotoxicity in Neuro2a Cells. Molecules, 2019; 24(7): 1366: 1-10.

5. Wang YH, Liou KT, Tsai KC, Liu HK, Yang LM, GSK-3 inhibition through GLP-1R allosteric activation mediates the neurogenesis promoting effect of P7C3 after cerebral ischemic/ reperfusional injury in mice. Toxicol Appl Pharmacol., 2018; 357: 88-105.

6. Blaya MO, Wasserman JM, Pieper AA, Sick TJ, Bramlett HM, Dietrich WD, Neurotherapeutic capacity of P7C3 agents for the treatment of Traumatic Brain Injury. Neuropharmacology, 2019; 145(Pt B): 268-282.

7. Hill CS, Menon DK, Coleman MP, P7C3-A20 neuroprotection is independent of Wallerian degeneration in primary neuronal culture. Neuroreport., 2018; 29(18): 1544-1549.

8. Karimi H, Heydari Dokoohaki M, Zolghadr AR, Ghatee $\mathrm{MH}$, The interactions of an $\mathrm{A} \beta$ protofibril with a cholesterol-enriched membrane and involvement of neuroprotective carbazolium-based substances. Phys Chem Chem Phys., 2019; 21(21): 11066-11078.

9. Gu C, Hu Q, Wu J, Mu C, Ren H, Liu CF, Wang G, P7C3 Inhibits LPS-Induced Microglial Activation to Protect Dopaminergic Neurons Against Inflammatory Factor-Induced Cell Death in vitro and in vivo. Front Cell Neurosci., 2018; 12: 400: 1-16.

10. Blaya MO, Wasserman JM, Pieper AA, Sick TJ, Bramlett HM, Dietrich WD, Neurotherapeutic capacity of P7C3 agents for the treatment of Traumatic Brain Injury. Neuropharmacology, 2019; 145(Pt B): 268-282.

11. Loris ZB, Pieper AA, Dietrich WD, The neuroprotective compound $\mathrm{P} 7 \mathrm{C} 3-\mathrm{A} 20$ promotes neurogenesis and improves cognitive function after ischemic stroke. Exp Neurol., 2017; 290: 63-73.

12. De Jesús-Cortés H, Miller AD, Britt JK, DeMarco AJ, De Jesús-Cortés M, Stuebing E, Naidoo J, VázquezRosa E, Morlock L, Protective efficacy of P7C3-S243 in the 6-hydroxydopamine model of Parkinson's disease. NPJ Parkinsons Dis., 2015; 1: 15010: 1-6.

13. Bordei (Telehoiu) AT, Nuță DC, Căproiu MT, Dumitrascu F, Zarafu I, Ioniță P, Bădiceanu CD, Avram S, Chifiriuc MC, Bleotu C, Limban C, Design, Synthesis and In Vitro Characterization of Novel Antimicrobial Agents Based on 6-Chloro-9 H-carbazol Derivatives and 1,3,4-Oxadiazole Scaffolds. Molecules, 2020; 25(2): 266: 1-18.

14. Vlad IM, Nuta DC, Chirita C, Caproiu MT, Draghici C, Dumitrascu F, Bleotu C, Avram S,Udrea AM, Missir AV, Marutescu LG, Limban C, In Silico and In Vitro Experimental Studies of New Dibenz[b,e]oxepin$11(6 \mathrm{H})$ one O-(arylcarbamoyl)-oximes Designed as Potential Antimicrobial Agents. Molecules, 2020; 25(2): 321: 1-18.

15. Avram S, Mernea M, Bagci E, Hritcu L, Borcan LC, Mihailescu D, Advanced structure-activity relationships applied to Mentha spicata L. subsp. Spicata essential oil compounds as AChE and NMDA ligands, in comparison with donepezil, galantamine and memantine New approach in brain disorders pharmacology. CNS Neurol Disord Drug Targets, 2017; 16(7): 800-811.

16. Dassault Systèmes BIOVIA, Discovery Studio Modeling Environment, Release 2017, San Diego, CA, USA: Dassault Systèmes, 2016.

17. Damnjanovic I, Kocic G, Najman S, Stojanovic S, Tomovic K, Ilic B, Veljkovic A, Pesic S, Smelcerovic A, Possible molecular mechanisms and pathways involved in BH3 mimetic activity of alpha-lipoic acid on human colon cancer cell line. Farmacia, 2019; 67(2): 226-234.

18. Veber DF, Johnson SR, Cheng HY, Smith BR, Ward KW, Kopple KD, Molecular properties that influence the oral bioavailability of drug candidates. J Med Chem., 2002; 45(12), 2615-2623.

19. ExPASy: SIBBioinformatics Resource Portal www.expasy.org.

20. www.molinspiration.com/cgi-bin/properties.

21. http://biosig.unimelb.edu.au/pkcsm/.

22. www.swisstargetprediction.ch/.

23. Alam MS, Nam YJ, Lee DU, Synthesis and evaluation of (Z)-2,3-diphenylacrylonitrile analogs as anti-cancer and anti-microbial agents. Eur J Med Chem., 2013; 69: 790-797.

24. Hadda TB, Rastija V, AlMalki F, Titi A, Tousani R, Mabkhot YN, Khalid S, Petra/Osiris/Molinspiration and Molecular Docking Analyses of 3-Hydroxy-Indolin2-one Derivatives as Potential Antiviral Agents. Curr Comput Aided Drug Des., 2019; 16: 1: 31878861.

25. www.solvobiotech.com/transporters/oct2.

26. Matsui T, Nakata T, Kobayashi Y, Localization of organic cation transporter 2 (OCT2) in monoaminergic and cholinergic axon terminals of the mouse brain. Neurosci Lett., 2016; 633: 118-124. 